\title{
Uptake of iron and its effect on grain refinement of pure magnesium by zirconium
}

\author{
P. Cao, Ma Qian, D. H. StJohn and M. T. Frost
}

\begin{abstract}
The uptake of iron by molten magnesium from uncoated new mild steel crucibles at temperatures $680 \mathrm{C}, 730 \mathrm{C}$, and $780 \mathrm{C}$ has been investigated. It was shown that the uptake of iron was sluggish at $680 \mathrm{C}$ and the use of $0 \cdot 05 \%$ zirconium addition could effectively suppress the increase in iron content within the first $2 \mathrm{~h}$ of holding at temperature. Rapid and severe uptake of iron was observed at $780 \mathrm{C}$. As a consequence, it was found that the grain refinement of pure magnesium achieved by $1 \%$ zirconium addition nearly vanished after $60 \mathrm{~min}$ hold at $780 \mathrm{C}$ due to the depletion of soluble zirconium. The uptake of iron at $730 \mathrm{C}$ was conspicuous but it was still controllable by use of $0 \cdot 05 \%$ zirconium addition within the first $60 \mathrm{~min}$ of holding at temperature. The work conducted using an aluminium titanite crucible and a boron nitride coated mild steel crucible at $730 \mathrm{C}$ further confirmed the highly detrimental influence of the uptake of iron on the grain refinement of pure magnesium by zirconium. The characteristic zirconium rich coring structures developed from circular to rosette like when the melt was held at $730 \mathrm{C}$ in an uncoated mild steel crucible, while no such evolution was observed when held in an aluminium titanite crucible at the same temperature. Recommendations to minimise the consumption of zirconium by the uptake of iron were made based on the results obtained from this investigation. The mechanism of grain refinement of magnesium by a low concentration of zirconium is discussed.

MST $/ 5925$
\end{abstract}

Keywords: Magnesium, Zirconium, Grain refinement, Iron

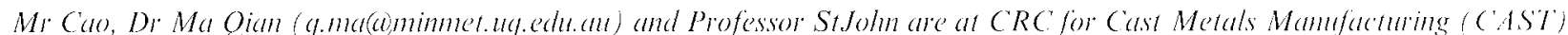

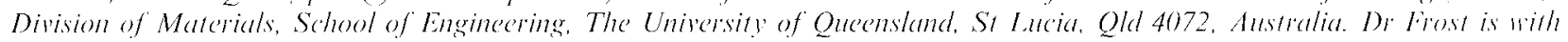

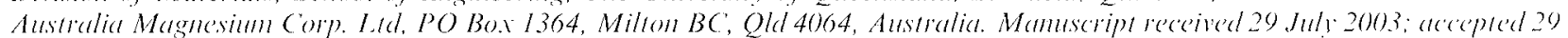
Seplember 2003

(:2004 IoM Commmanications Lud. Published by Mancy for the Institute of Materials, Minerals and Mining.

\section{Introduction}

Zirconium is a potent grain refiner for magnesium alloys that do not contain aluminum such as $\mathrm{Mg}$. Zn or $\mathrm{Mg}$. RE ... Zn alloys with or without calcium (zirconium forms stable intermetallic phases with aluminum). ${ }^{3}$ Zirconium is also a powerful iron removal agent. It reacts with any iron in molten magnesium (magnesium alloys containing zirconium normally contain less than 50 ppm of iron ${ }^{4}$ Becausc of this, when introduced into a magnesium melt, rirconium will first remove iron from the melt. The resultant very low iron content will conseguently provide an aggressive driving fore for the uptake of iron by the melt from the alloying vessel, which is normally made of mild steel. This uptake of iron has two consequences. The first is the rapid consumption of zirconium in the melt and the second is the increased buildup of sludge at the bottom of the crucible due to the formation of iron zirconium intermetallic compounds. As such, the uptake of iron has been one of the key issues affecting alloying zirconium to magnesium in the commercial production of magnesium alloys containing zirconium.

In order to offset the influence of the uptake of iron on the consumption of zirconium, an excess of zirconium is usually alloyed to the melt in practice. Although this remedy has technically worked, zirconium is a very expensive alloy ing material. Moreover, the use ol exeessive zirconitum often produces a large amount of sludge, leading to increased operating cost and low yick of expensive magnesium alloys containing zirconium. Unfortunately, few economically viable altemative materials that are suitable for processing molten magnesium currently exist other than the use of mild steel crucibles. On the other hand, although the detrimental inffucnee of the uptake of iron has long been recognised in the commercial production of magnesium alloys containing rirconium, little detailed information can be found in the literature about this important issue. This work has been carried out to investigate the influence of the uplake of iron on the consumption of rirconium and the subsecpuent grain refinement of the final as cast alloy under various operating conditions. For comparison, iron free ceramic crucibles have also been used. Recommendations to minimise the consumption of zirconitum by the uptake of iron are made based on the results obtaned from this investigation.

\section{Experimental procedure}

Melting of magnesium was conducted in an electrical resistance fulnace with temperature control in the range of \pm .3 $5 \mathrm{~K}$. The protective cover gas used was $1.0 \% \mathrm{SI} \%$ in a mixture of $49 \%$ dry ail and $50 \% \mathrm{CO}_{2}$. The uplake of iron was investigated at three different lemperatures. 680 ( $730 \mathrm{C}$ and $780 \mathrm{C}$. Three new mild stecl crucibles (innel diameter $130 \mathrm{~mm}$; depth $240 \mathrm{~mm}$ ) were used in order to avoid the seasoning effect of firconium that oceurs from the repeated use of steel crucibles. ${ }^{4}$ Commercial purity magnesium ingots were used as the base material. The zirconium was introduced in the form of a $\mathrm{Mg} 30 \mathrm{Zr}$ master alloy named AM-cast." Two tests were conducted at calch temperature and each new crucible was thus used twice. In each lest, the weight of magnesium charge was $-4 \mathrm{~kg}$. The depth of melt in the crucible was $\sim 190 \mathrm{~mm}$. The specific contale surface, calculated as the ratio of the total melterucible contact surface to the volume of the melt, was $\sim 0.36 \mathrm{~cm}$ In the first test conducted alt each temperature, $(0 \cdot 0.5 \%$ trirconium was added while in the second test $0.25 \%$ in zirconium was used. The melt was hand stired using a boron nitride (BN) coated mild sted spoon for 5 min al $\sim 100$ strokes min ${ }^{\prime}$ following addition of the AM-cast master alloy. After that, the melt was held at temperature for $6 \mathrm{~h}$ and small cone samples (diameter $20 \mathrm{~mm} \times$ diameter $30 \mathrm{~mm} \times$ height $25 \mathrm{~mm}$ ) were taken from the top of the melt at different holding times using a $B N$ coated cone latde. 


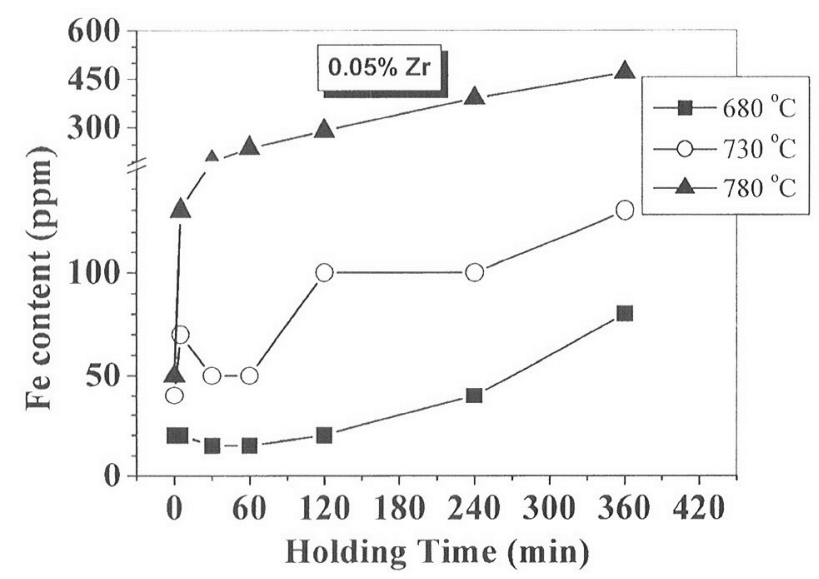

1 Uptake of iron by molten magnesium at $680 \mathrm{C}, 730 \mathrm{C}$, and $780 \mathrm{C}$ with $0.05 \% \mathrm{Zr}$ addition in each case

Grain refinement experiments were conducted at 680 , 730 , and $780^{\circ} \mathrm{C}$ using three other new mild steel crucibles for comparison. The zirconium addition was fixed at $1 \%$ in these tests. Similar melting and sampling procedures were followed but the holding time was limited to $2 \mathrm{~h}$ in each test. To further clarify the influence of the uptake of iron on the grain refinement of pure magnesium by zirconium, similar grain refinement tests were conducted using aluminium titanite crucibles (nominal composition: $\mathrm{AlTi}_{2} \mathrm{O}_{5}$ ) with the dimensions diameter $80 \mathrm{~mm} \times$ depth $190 \mathrm{~mm}$ and a $\mathrm{BN}$ coated mild steel crucible.

Each cone sample was sectioned into halves along its axis. One half was ground and polished for metallographic analysis and the other half for wet chemical analysis. The etchant used contained $10 \mathrm{~mL}$ acetic acid, $4.2 \mathrm{~g}$ picric acid $10 \mathrm{~mL} \mathrm{H} \mathrm{H}_{2} \mathrm{O}$, and $70 \mathrm{~mL}$ ethanol. The grain size was measured from the central region of each sample in accordance with the intercept method described in the ASTM standard E112-96. The grain structures of each sample were analysed using a Philips XL-30 scanning electron microscope (SEM) in the backscattered electron (BSE) mode, assisted by an energy dispersive X-ray spectrometer (EDS). Quantitative analyses were performed using a JXA-8800L electron probe microanalyser (EPMA) with a beam voltage of $15 \mathrm{kV}$. The iron and zirconium contents were chemically determined by inductively coupled plasma atomic emission spectroscopy (ICP-AES) based on an approach previously developed for the determination of soluble zirconium in magnesium alloys. ${ }^{6}$

\section{Results}

\section{UPTAKE OF IRON FROM MILD STEEL CRUCIBLES}

Figure 1 shows the uptake of iron as a function of holding time at each of the three temperatures 680,730 , and $780^{\circ} \mathrm{C}$ with $0.05 \%$ zirconium addition in each case. A gradual increase in the iron content was observed after $2 \mathrm{~h}$ at $680^{\circ} \mathrm{C}$ but before that little increase was detected. The total increase in the iron content registered $60 \mathrm{ppm}$ after $6 \mathrm{~h}$ at $680^{\circ} \mathrm{C}$. By contrast, a conspicuous increase in the iron content was observed after $2 \mathrm{~h}$ at $730^{\circ} \mathrm{C}$. The length of time registering little increase in the iron content was reduced from $2 \mathrm{~h}$ at $680^{\circ} \mathrm{C}$ to $1 \mathrm{~h}$ at $730^{\circ} \mathrm{C}$. When alloyed and held at $780^{\circ} \mathrm{C}$, the melt demonstrated a rapid and significant increase in the iron content with increasing holding time. The iron content increased by $80 \mathrm{ppm}$ within the first $5 \mathrm{~min}$ at $780^{\circ} \mathrm{C}$. In fact, the increase in the iron content started before the melt reached $780^{\circ} \mathrm{C}$, as can be inferred from the data corresponding to zero holding time shown in Fig. 1,

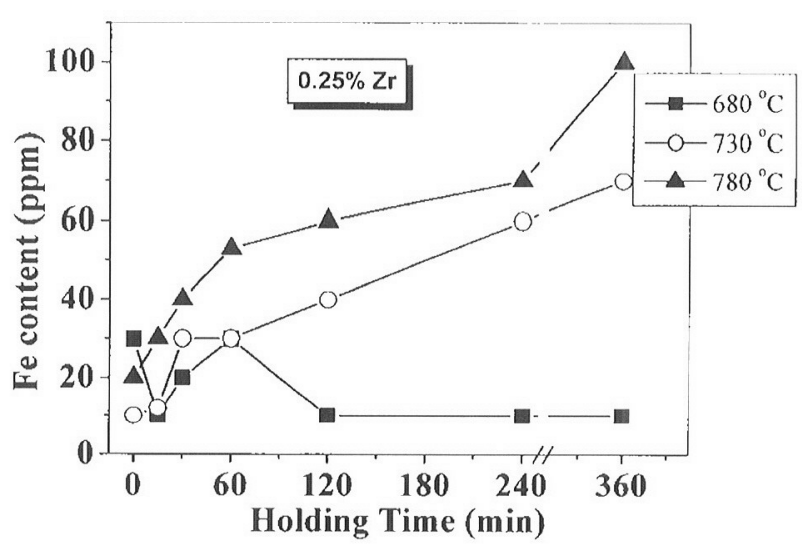

2 Uptake of iron by molten magnesium at $680 \mathrm{C}, 730 \mathrm{C}$ and $780 \mathrm{C}$ with $0.25 \% \mathrm{Zr}$ addition in each case

suggesting that the $0.05 \%$ zirconium addition had been consumed before the melt reached $780^{\circ} \mathrm{C}$.

The increase in the iron content with $0.25 \%$ zirconium addition was much slower at each temperature, as shown in Fig. 2. Little increase in the iron content was observed throughout $6 \mathrm{~h}$ of holding at $680^{\circ} \mathrm{C}$, while at $730^{\circ} \mathrm{C}$ the increase in $\mathrm{Fe}$ content was limited to $60 \mathrm{ppm}$ after $6 \mathrm{~h}$ at temperature. The use of $0.25 \%$ zirconium also significantly suppressed the increase in the iron content at $780^{\circ} \mathrm{C}$. For example, the $\mathrm{Fe}$ content increased mildly from 20 to $100 \mathrm{ppm}$ after $6 \mathrm{~h}$ at $780^{\circ} \mathrm{C}$ compared to a dramatic increase from 50 to $470 \mathrm{ppm}$ in the case of $0 \cdot 05 \%$ zirconium addition.

\section{GRAIN REFINEMENT OF PURE MAGNESIUM BY ZIRCONIUM WHEN ALLOYED IN UNCOATED MILD STEEL CRUCIBLES}

Figure 3 shows the average grain size measured on samples taken from the grain refinement tests conducted at 680, 730, and $780^{\circ} \mathrm{C}$. In each test, the first sample was taken immediately after 5 min manual stirring. Similar to the observations made from the use of boron nitride coated mild steel crucibles, ${ }^{3}$ the average grain size was found to increase with increasing holding time at each temperature. However, the growth rate was obviously different at each temperature. As shown in Fig. 3, the average grain size increased from 79.2 to $102.7 \mu \mathrm{m}$ after the melt was held for $2 \mathrm{~h}$ at $680^{\circ} \mathrm{C}$ (curve 1) while an increase from 89 to $190 \mu \mathrm{m}$ was observed after the same holding time at $730^{\circ} \mathrm{C}$ (curve 2). On the other hand, the $2 \mathrm{~h}$ of holding at $780^{\circ} \mathrm{C}$ led to a dramatic increase

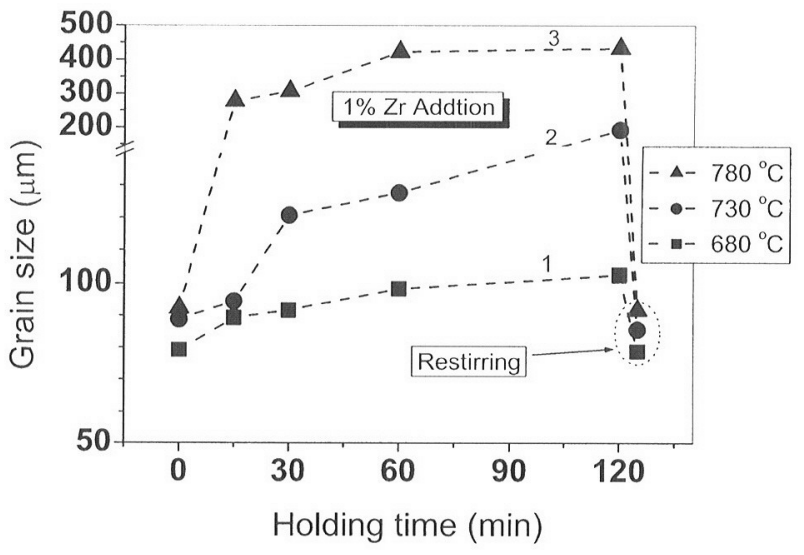

3 Average grain size as a function of holding time at $680^{\circ} \mathrm{C}, 730^{\circ} \mathrm{C}$, and $780^{\circ} \mathrm{C}$ when uncoated mild steel crucibles were employed 

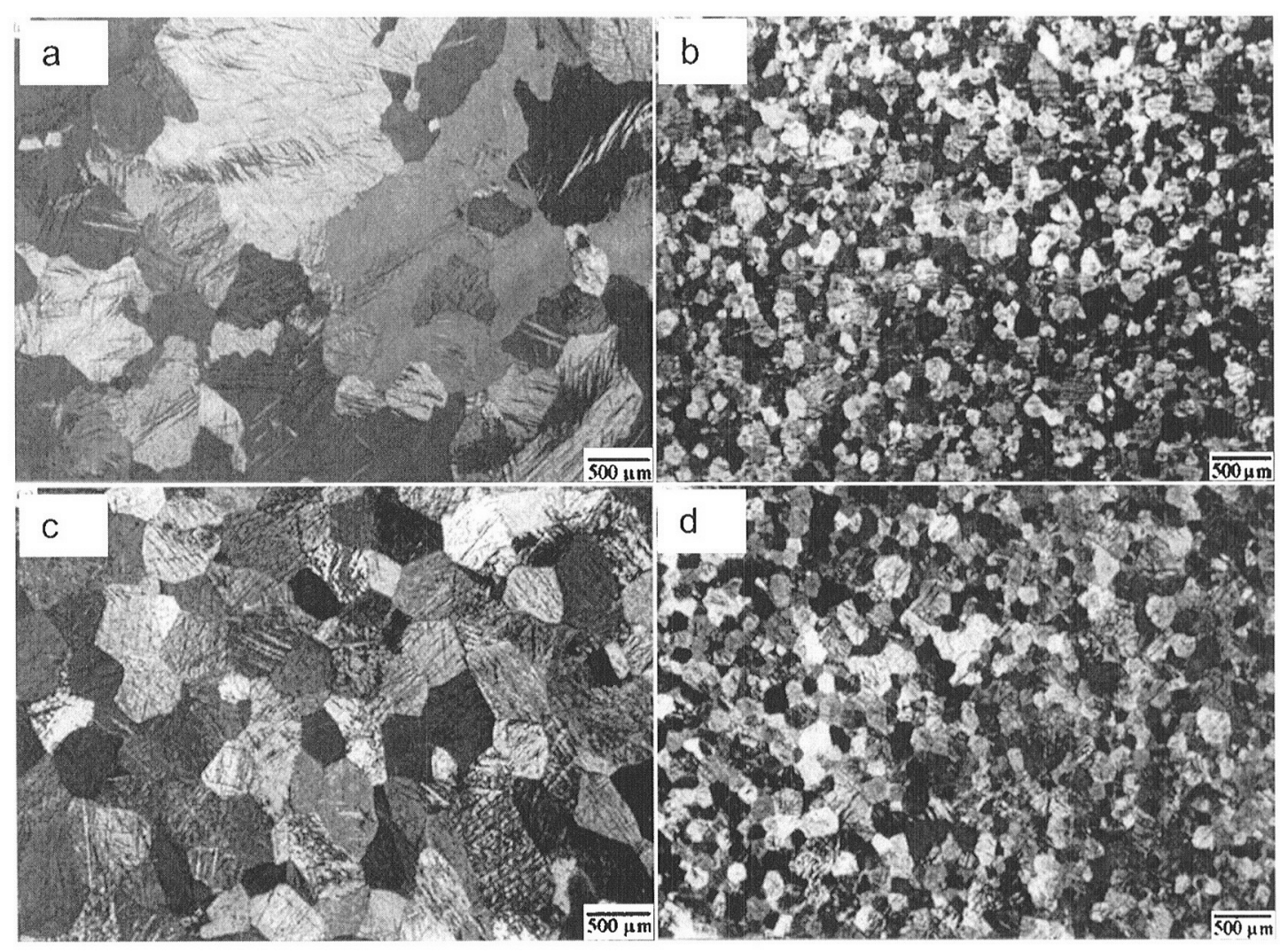

4 Typical views of the grain structures of samples taken at $780^{\circ} \mathrm{C}$ a before adding zirconium, average grain size (AGS) $860 \mu \mathrm{m} ; b$ after 5 min stirring following addition of zirconium, AGS $=92.3 \mu \mathrm{m} ; c$ after $2 \mathrm{~h}$ of holding, AGS $=433 \mu \mathrm{m}$; $d$ after restirring the melt for $2 \mathrm{~min}, \mathrm{AGS}=\mathbf{9 1 . 7} \mu \mathrm{m}$. An uncoated mild steel crucible was used in this test

in the average grain size from 92 to $433 \mu \mathrm{m}$ (curve 3 ). Table 1 shows the chemical analytical results of both soluble and total zirconium contents of samples taken before settling and after $2 \mathrm{~h}$ of settling. There was a significant decrease in the soluble zirconium content after $2 \mathrm{~h}$ of settling at $780{ }^{\circ} \mathrm{C}$ (down from $0 \cdot 36 \%$ to $0 \cdot 19 \%$ ), while the decrease in the soluble zirconium content at $680^{\circ} \mathrm{C}$ was negligible. At $730^{\circ} \mathrm{C}$, the soluble zirconium content registered a limited decrease from $0 \cdot 42 \%$ to $0 \cdot 37 \%$. This is a tolerable loss, suggesting that if a magnesium melt is alloyed and held at $730^{\circ} \mathrm{C}$ in an uncoated mild steel crucible for no more than $2 \mathrm{~h}$, then the consumption of zirconium by the uptake of iron will not be a major concern. The total zirconium content dropped conspicuously at each temperature due to the settling of undissolved zirconium particles. ${ }^{3,6-9}$

Figure $4 a-d$ show typical views of the grain structures of samples taken before adding zirconium, after $5 \mathrm{~min}$ of stirring following addition, after $2 \mathrm{~h}$ of settling at $780^{\circ} \mathrm{C}$, and after restirring the melt. It has been shown that restirring the melt can bring the average grain size back to the level obtained before settling when alloyed in boron nitride coated crucibles or magnesia crucibles due to the positive role of undissolved zirconium particles. ${ }^{6-9}$ As shown in Fig. 3, restirring the melt also worked to restore the average grain size of the final alloy at each temperature in this investigation. The soluble and total zirconium contents of the samples taken after restirring the melt have also been listed in Table 1. As can be seen, the reason why restirring the melt worked at $680^{\circ} \mathrm{C}$ and $730^{\circ} \mathrm{C}$ was due primarily to the increased total zirconium content, while at $780^{\circ} \mathrm{C}$ it was because of the obvious increase in both the soluble zirconium content and the total zirconium content, of which the former played a more profound role. ${ }^{6-9}$

\section{GRAIN REFINEMENT OF PURE MAGNESIUM BY ZIRCONIUM WHEN ALLOYED IN IRON FREE CERAMIC CRUCIBLES AND COATED MILD STEEL CRUCIBLES}

In order to further clarify the influence of the uptake of iron, similar tests were carried out using iron free aluminum titanite crucibles at $680^{\circ} \mathrm{C}$ and $730^{\circ} \mathrm{C}$ and a boron nitride coated mild steel crucible at $730^{\circ} \mathrm{C}$. The results obtained from these tests are shown in Fig. 5. For easy comparison, the data shown in Fig. 3 for curves 1 and 2 are replotted in Fig. 5. As expected, not much difference was observed at $680^{\circ} \mathrm{C}$ because of the less severe uptake of iron at this temperature. However, the difference was conspicuous at $730^{\circ} \mathrm{C}$. The use of an aluminum titanite crucible and a boron nitride coated mild steel crucible led to a much slower increase in the average grain size than did the use of an uncoated mild steel crucible. The limited increase in the

Table 1 Soluble and total zirconium contents of samples taken from grain refinement tests conducted at different temperatures using uncoated mild steel crucibles and aluminium titanite crucible. Analytical method: ICP-AES

\begin{tabular}{|c|c|c|c|c|c|c|c|}
\hline \multirow[b]{2}{*}{ Crucible } & \multirow[b]{2}{*}{ Temperature } & \multicolumn{2}{|l|}{ Before settling } & \multicolumn{2}{|l|}{$2 \mathrm{~h}$ of settling } & \multicolumn{2}{|l|}{ Restirring } \\
\hline & & Soluble Zr, \% & Total Zr, \% & Soluble Zr, \% & Total Zr, \% & Soluble Zr, \% & Total Zr, \% \\
\hline \multirow[t]{3}{*}{ Uncoated mild steel } & $680^{\circ} \mathrm{C}$ & 0.43 & 0.62 & 0.41 & 0.43 & 0.37 & 0.58 \\
\hline & $730^{\circ} \mathrm{C}$ & $0 \cdot 42$ & 0.65 & $0 \cdot 37$ & $0 \cdot 41$ & $0 \cdot 37$ & 0.57 \\
\hline & $780^{\circ} \mathrm{C}$ & $0 \cdot 36$ & 0.62 & $0 \cdot 19$ & $0 \cdot 30$ & 0.34 & 0.46 \\
\hline Aluminium titanite & $730^{\circ} \mathrm{C}$ & 0.45 & 0.62 & $0 \cdot 45$ & $0 \cdot 48$ & $0 \cdot 48$ & 0.60 \\
\hline
\end{tabular}




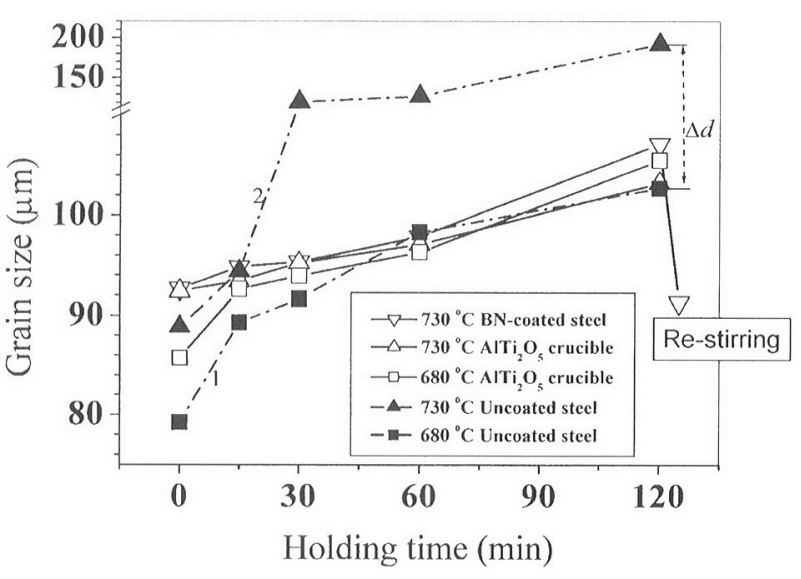

5 Average grain size as a function of holding time at $680^{\circ} \mathrm{C}$ and $730^{\circ} \mathrm{C}$ when aluminium titanite crucible and boron nitride coated steel crucible used. $1 \% \mathrm{Zr}$ was alloyed to the melt in each test. Curves 1 and 2 reproduced from Fig. 3 for comparison

average grain size observed from the use of both an aluminum titanite crucible and a BN coated crucible is mainly attributed to the settling of undissolved zirconium particles in the melt. ${ }^{7-9}$ By contrast, the difference in grain size $\Delta d$ arising from the use of an uncoated mild steel crucible and an aluminum titanite crucible at $730^{\circ} \mathrm{C}$, as shown in Fig. 5, is due primarily to the uptake of iron by molten magnesium from the uncoated mild steel crucible at $730 \mathrm{C}$. Figure $6 a-c$ show typical views of the grain structures of respective samples taken from the test conducted at $730^{\circ} \mathrm{C}$ in an aluminum titanite crucible

\section{TYPICAL GRAIN STRUCTURES}

The characteristic zirconium rich coring structures of a magnesium alloy containing zirconium are readily visible when observed under an SEM in the BSE mode. ${ }^{10}$ Figures $7 a-d$ show typical views of the zirconium rich coring structures observed in samples taken from the grain refinement test conducted at $730^{\circ} \mathrm{C}$ using an uncoated mild steel crucible. The zirconium rich cores were generally elliptical or circular after 5 min stirring following the addition of 1\% zirconium (Fig. 7a). Little change was observed in their morphologies after $30 \mathrm{~min}$ of holding at $730^{\circ} \mathrm{C}$ except for a decrease in the number density (Fig. 7b). However, most of the elliptical or circular cores developed into rosette like structures after a further 30 min of holding at temperature (Fig. 7c). Similar observations were made from samples taken from the grain refinement test conducted at $780^{\circ} \mathrm{C}$ using an uncoated mild steel crucible excep that the rosette like cores were observed after only 15 min hold at 780 (". By contrast, no such morphological changes were observed from samples laken from similar grain relinement tests conducted using an iron frec aluminum titanite crucible, as shown in lig. $8 a$ and b. Quantitative compositional analyses by I:PM $\mathrm{A}$ showed that about $0.6 \ldots 1.5 \%$ rireonium was delected in the eentral regions of some of the circular eores observed in the sample shown in fig. $7 \mathrm{~b}$, whereas $0.37 \quad 0.5 \%$ was observed in the central regions of some of the rosette like cores in the sample shown in lig. 76

\section{Discussion}

CONSUMPTION OF SOLUBLE ZIRCONIUM BY THE UPTAKE OF IRON

It is known within the magnesium industry that zirconium removes iron from molten magnesium by lorming $\mathrm{le} / \mathrm{r}$
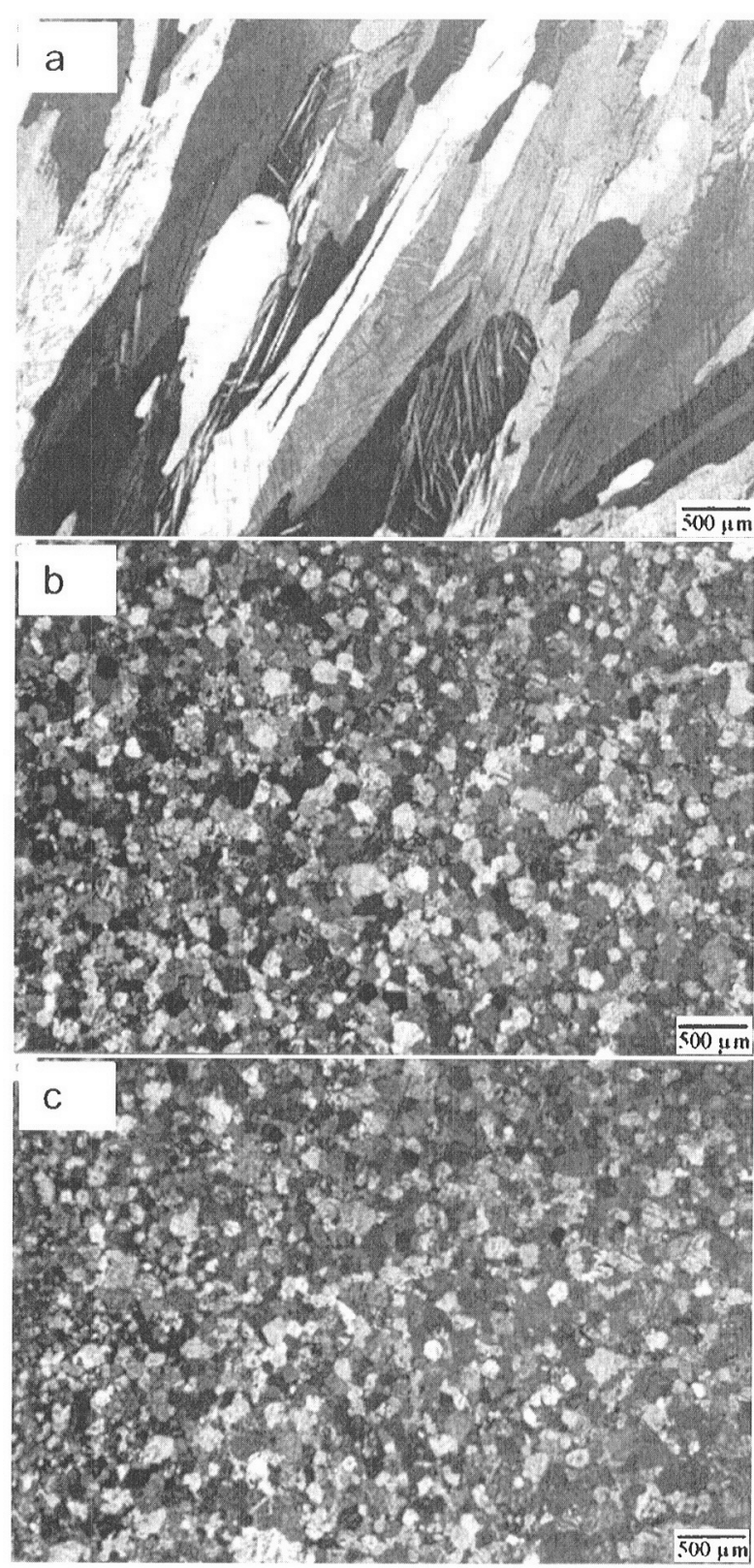

6 Typical views of grain structure of samples taken from grain refinement test conducted at $730 \mathrm{C}$ using aluminium titanite crucible: a before adding zirconium AGS $=1090 \mu \mathrm{m} ; b$ after $2 \mathrm{~h}$ settling at $730^{\circ} \mathrm{C}, \mathrm{AGS}$ $103 \mu \mathrm{m} ; c$ after restirring melt for $2 \mathrm{~min}, \mathrm{AGS}=91 \mu \mathrm{m}$

intermetallies and these intermetallic particles settle out very fast in molten magnesium due to their higl densitios. To confirm this understanding, two sepatrate experiments were conducted at the $30 \mathrm{~kg}$ scale of magnesium melt using an uncoated mikl stecl crucible (dianneter $250 \mathrm{~mm}$; depth $500 \mathrm{~mm}$ ). In each test, $30 \mathrm{~kg}$ of pure magnesium ingots containing 160 l 80 ppm of iron was molted at $730 \mathrm{C}$ Then $1 \% / 1 \mathrm{r}$ was added to the melt in the form of Mg 33.3Z master alloy, followed by 10 min stirring at $250 \mathrm{rev}$ min 10 assist the dissolution of zirconium. The melt was allowed to settle for 15 min before two plate samples $(160 \times 140 \times 30 \mathrm{~mm})$ were sand cast. A sludge samplo was taken from the bottom of the crucible alter casting. The iron and rirconium contents in both lhe plate sample and the sludge sample were analysed using a chemical approach developed previously. "Table 2 shows the analytical results obtained fiom these samples. In both cases, a substantial difference was observed between the total iron content in the plate sample and the total iron content in the sludge 

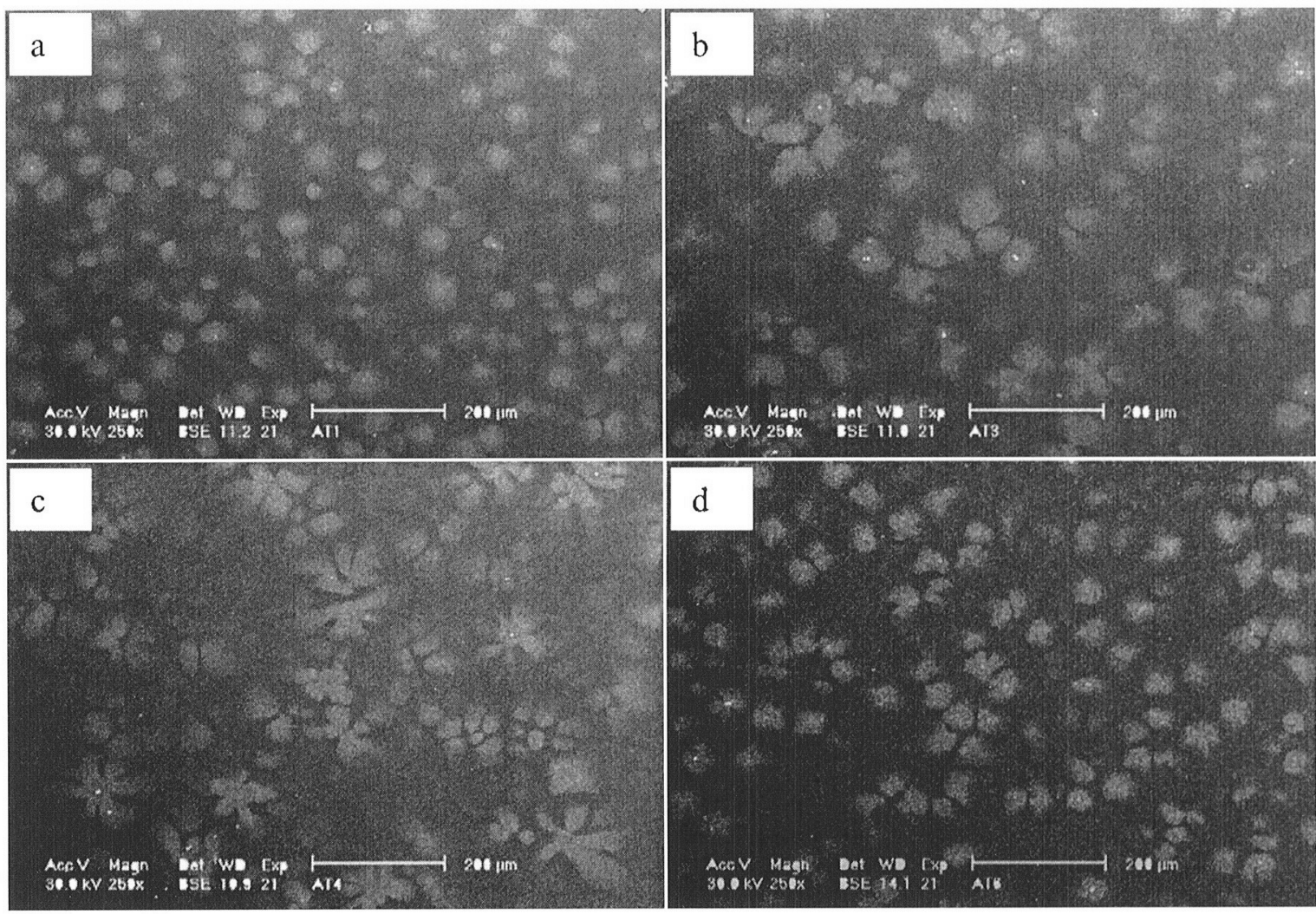

7 Morphological evolution of zirconium rich coring structures observed from samples taken from the grain refinement test conducted at $730^{\circ} \mathrm{C}$ using uncoated mild steel crucible: a after 5 min stirring following addition of zirconium; $b$ after $30 \mathrm{~min}$ of holding at temperature; $c$ after 60 min of holding at temperature; $d$ after restirring melt for 2 min

sample, where the total iron content refers to the sum of the iron in solution (i.e. the soluble iron) and the iron in various iron contalining intermetallies (i.e. the insoluble iron). On the other hand, little difference was observed between the soluble iron content and the total iron content in each plate sample. These observations support the understanding that zirconium removes iron from molten magnesium by forming $\mathrm{Fe}-\mathrm{Zr}$ intermetallics, which then quickly settle out in molten magnesium. The settling time is typically around $30 \mathrm{~min}$ after alloying a magnesium melt with zirconium in the commercial production of magnesium alloys containing zirconium in order to climinate the undesirable $\mathrm{Fe}-\mathrm{Zr}$ intermetallic particles and undissolved large zirconium particles. The exceedingly high zirconium contents detected in the sludge samples were due to settled undissolved zirconium particles.

According to the binary $\mathrm{Fe}-\mathrm{Zr}$ phase diagram, ${ }^{11}$ zirconium and iron can form four different types of $\mathrm{Fe}-\mathrm{Zr}$ intermeallic phases, namely, $\mathrm{FeZr}_{3}, \mathrm{FeZr}_{2}, \mathrm{Fe}_{2} \mathrm{Zr}$, and $\mathrm{Fe}_{23} \mathrm{Zr}_{6}$. However, it is not clear exactly what type of $\mathrm{Fe}-\mathrm{Zr}$ intermetallic forms in molten magnesium. Early work by Schneider and Stendel ${ }^{4}$ shows that there is a mutual solubility relationship existing between zirconium and iron in molten pure magnesium. Figure 9 shows the mutual solubility relationships between zirconium and iron in the molten magnesium at 700,750 , and $800^{\circ} \mathrm{C}^{4}$ Assuming the formation of a $\mathrm{Fe}-\mathrm{Zr}$ intermetallic phase in molten magnesium is described by the following reaction

$$
m \mathrm{Fe}+n \mathrm{Zr} \leftrightarrow \mathrm{Fe}_{\mathrm{m}} \mathrm{Zr}_{\mathrm{n}}(\mathrm{s})
$$

then the solubility product constant, Ksp, can be written as

$$
K s p=[\mathrm{Fe}]^{\mathrm{m}}[\mathrm{Zr}]^{\mathrm{n}}
$$

where $[\mathrm{Fe}]$ and $[\mathrm{Zr}]$ are the concentrations of $\mathrm{Fe}$ and $\mathrm{Zr}$ in the melt. Using equation (2), the logarithms of the concentrations of $\mathrm{Fe}$ and $\mathrm{Zr}$ can be expressed linearly by

$$
\log [\mathrm{Zr}]=-\frac{m}{n} \log [\mathrm{Fe}]+\frac{1}{n} \log K s p .
$$

All of the mutual solubility relationships shown in Fig. 9 obviously obey the linear relationship predicted by equation (3). Moreover, the slope of each of the three lines shown in Fig. 9 was found to be just equal to -2 , suggesting that $\mathrm{Fe}_{2} \mathrm{Zr}$ is formed in molten magnesium in the temperature range between 700 and $800^{\circ} \mathrm{C}$ rather than $\mathrm{FeZr}_{3}, \mathrm{FeZr}_{2}$ and $\mathrm{Fe}_{23} \mathrm{Zr}_{6}$. In this work, the consumption of soluble zirconium in the magnesium melt is regarded as a consequence of the formation of $\mathrm{Fe}-\mathrm{Zr}$ intermetallic, probably $\mathrm{Fe}_{2} \mathrm{Zr}$. Transmission electron microscopy may be needed to clarify the

\begin{tabular}{|c|c|c|c|c|c|}
\hline Trials & Sample & Soluble Fe, \% & Total Fe, \% & Soluble Zr, \% & Total Zr, \% \\
\hline 1 & $\begin{array}{l}\text { Plate sample† } \\
\text { Sludge sample }\end{array}$ & $<0.005$ & $\begin{array}{c}<0.005 \\
0.56\end{array}$ & $0 \cdot 43$ & $\begin{array}{l}0.52 \\
18.2\end{array}$ \\
\hline 2 & $\begin{array}{l}\text { Plate sample† } \\
\text { Sludge sample }\end{array}$ & $<0.005$ & $\begin{array}{c}<0.005 \\
0.23\end{array}$ & $0 \cdot 53$ & $\begin{array}{l}0.66 \\
4.35\end{array}$ \\
\hline
\end{tabular}
nature of the intermetallic particles formed in the melt.

Table 2 Settling of $\mathrm{Fe}_{\mathrm{m}} \mathrm{Zr}_{\mathrm{n}}$ intermetallic particles in molten magnesium*

*In these two trials, $30 \mathrm{~kg}$ of magnesium ingot was melted at $730^{\circ} \mathrm{C}$ using an uncoated mild steel crucible (diameter $250 \mathrm{~mm}$, height $500 \mathrm{~mm}$ ) $1 \% \mathrm{Zr}$ was added to the melt followed by $10 \mathrm{~min}$ stirring at $250 \mathrm{rev} \mathrm{min}^{-1}$. Plate samples were sand cast after the melt settled for 15 min. tDimensions of sand cast plate samples: $160 \times 140 \times 30 \mathrm{~mm}$. 


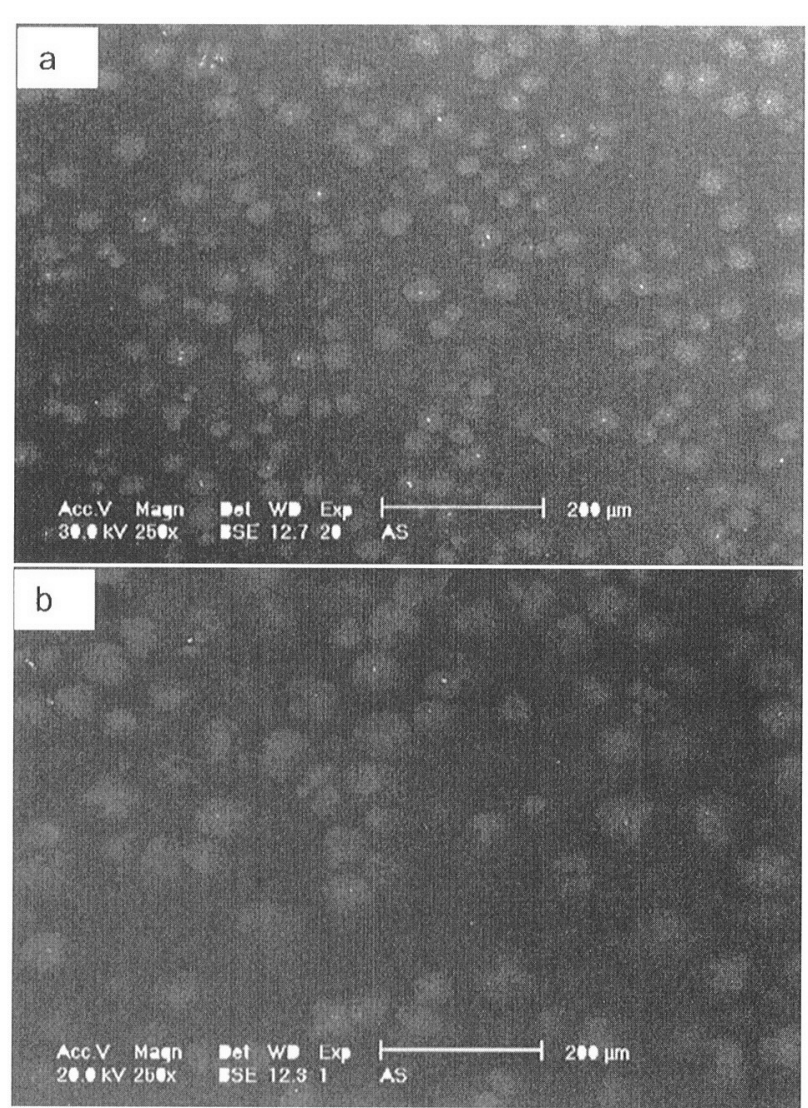

8 Typical views of zirconium rich coring structures observed from samples taken from grain refinement test conducted at $730 \mathrm{C}$ using aluminium titanite crucible: a after $5 \mathrm{~min}$ stirring following addition of zirconium; b after $2 \mathrm{~h}$ settling at $730 \mathrm{C}: 1 \% \mathrm{Zr}$ was added to the melt in this test; zirconium rich cores remained circular or elliptical after $2 \mathrm{~h}$ settling at $730 \mathrm{C}$

\section{EFFECT OF UPTAKE OF IRON ON GRAIN REFINEMENT}

Il has been clarilied that grain refinement of magnesium by airconium is matuly allributable to the soluble firconium content in the mell betore casting, although insoluble zitconium as subiably sized undissolved zirconium parlicles also plays a positive role. 6.8 " As evident from companing ligs. I and 3, there is good agreement between the trend in uplake of iron and the trend in increase in the average grain size al calch temperature. Since the uptake of iron by a low joon manuesium mell from a mild steel crucible is unavoidable at high temperature $(\geqslant 730 \mathrm{C}$ ). the procedures used to alloy firconium fo magnesium should be designed to cnsure a minimal consumption of zireonium based on the dissolution kineties of zirconium in molten magnesium and the kinetics of the uptake of irom. For example, it has been lound that stirring or pulding plays a key role in assisting the dissolution of zireoniun into molten magnesium when introduced in the form of a $\mathrm{Mg} \mathrm{Zr}$ master alloy. and without proper stirring or puddling litte dissolution aceuss." I2 In addition, il has been found that melt temperalure has litfle influenee on the dissolution of a Mg \% master alloy in molten magnesium in the range $680780(9$. Therelore, in order to reduce the consumption of zirconium, the master alloy should be introduced into the mell inmedialdy before casting at the lowest melt temperature lhat is suitable for casting. for example. 730 C. il practical. Also, stirring or pudtling should be applicd about 30 min belore casting.

The gradual increase in the average grain size shown in lig. 5 for the two dests condacted using an aluminium

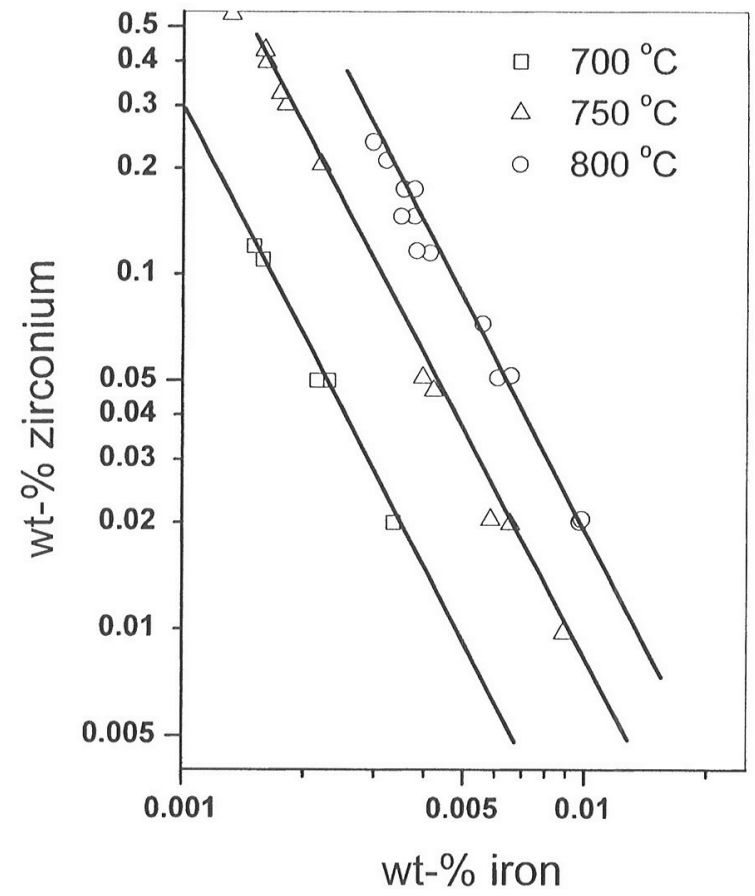

9 Mutual solubility relationship between $\mathrm{Zr}$ and $\mathrm{Fe}$ in molten magnesium at different temperatures (replotted from Ref. 4)

litanite crucible and the test conducted using a $B N$ coated mild steel crucible is manly due to the settling of undissolved zirconium particles with increasing holding lime in the crucible, "as ean be judged from the soluble and total rirconium results shown in Table 1 . This is similar to the gradual increase in the average grain size observed at $680^{\circ} \mathrm{C}$ when a mild sted crucible was used (lig. 3). It can also be seen from fig. 5 that the growth rate of gratin size over the holding time was nearly the same in all cases studied at both $680 \mathrm{C}$ and $730 \mathrm{C}$. This coincides with the theoretical predictions that melt temperature has a negligible effoct on the setuling behaviou of undissolved zirconium particles in molten magnesium. ${ }^{7}$

Restirring the melt can bring setted undissolved firconium particles from the bottom into the melt, therefore providing more nucleants for magnesium grains during the solidification of the final alloy. This is the mechanism by which restirring works when a ceramic crucible or a well coated mild steel crucible is used. However, the mechanism differs when an uncoated mild steel crucible is employed, particularly when there is severe uplake of iron. This has been the case for the test conducted at $780 \mathrm{C}$. where the soluble zirconium content decreased firom $0 \cdot 36 \%$ to $0 \cdot 19 \%$ alter 2 h holding alt temperature and increased to $0 \cdot 34 \%$ after restiring the melt (Table 1). In these cases, restiring has played a role in both reatetivating the dissolution of zirconium into the melt and bringing the particles from the bottom back to the body of the melt. It should be noted that apart from bringing settled undissolved firconium particles from the bottom into the melt, restirring also simultancously brings setted Fe Zr intermetallic particles back to the melt. The possibility that these Fe $\mathrm{Zr}$ intermetallic particles maly be returned to the melt, cither partially or completely, by vigorous restirring cannol be excluded. This will be governed by the mulual solubility relationship existing between fic and $7 . \mathrm{r}$ in the melt, as shown in Fig. 9. Considering that the iron level in a magnesium alloy containing zitconium is typically less than $50 \mathrm{ppm}$. fine experimental work is needed to clarify this point. 


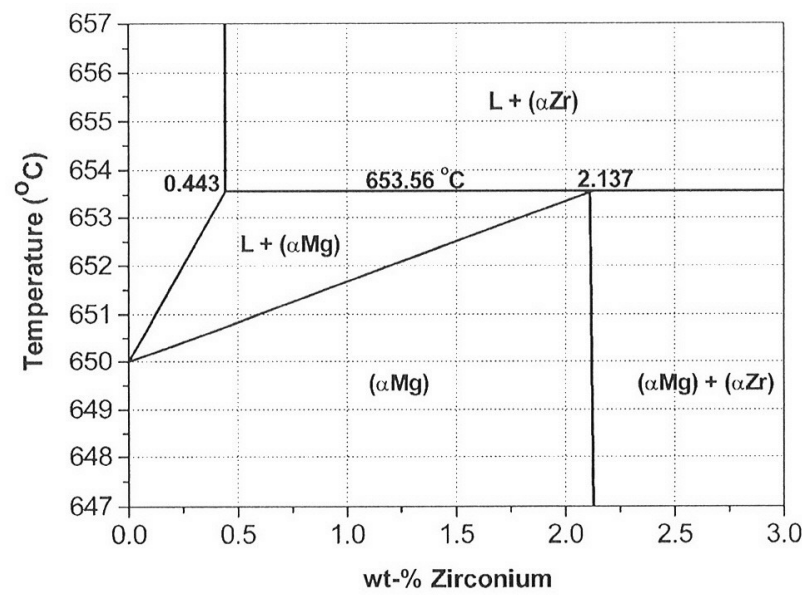

10 Portion of $\mathrm{Mg}$ rich region of the $\mathrm{Mg}-\mathrm{Zr}$ phase diagram (after Refs. 14,15)

\section{MECHANISM OF GRAIN REFINEMENT OF MAGNESIUM BY LOW CONCENTRATION OF ZIRCONIUM}

It is generally agreed that the grain refinement of magnesium by zirconium occurs via a peritectic reaction. $2,10,1$. According to the $\mathrm{Mg}$... $\mathrm{Zr}$ phase diagram, ${ }^{14.15}$ in order for the peritectic raction to occur, the melt needs to contain $\sim 0.45 \%$ zirconium in solution when cooled in an equilibrium state (Fig. 10). However, obvious grain refinement is observed with a low concentration of rirconium in the liquid. Figure 11 shows a typical view of the microstructure of a sample taken from the grain refinement test conducted at $780 \mathrm{C}$ using an uncoated mild steel crucible. The melt was held for $2 \mathrm{~h}$ at $780 \mathrm{C}$ before the sample was taken. As a result, the sample contains only $0 \cdot 19 \%$ zirconium in solution due to the uptake of iron (Table 1). The total zirconium content is $0.30 \%$, which is also well below $0.45 \%$. As shown in Fig. 11, characteristic zirconium rich structures still form in this alloy. Quantitative microprobe analyses showed that almost all of the soluble rirconium contained in the alloy is concentrated in these structures and other areas basically contain no zirconium. This is similar to the observations made previously for the case of a high rirconium content alloy. ${ }^{10}$ In addition, fine zirconium particles can also be found at the centres of the rosette like zirconium rich structures shown in Fig. 11. For example, a well developed rosette like structure, which contains a tiny zirconium particle at the centre, a circular core surrounding the particle, and a number of dendrite branches surrounding the core, has been captured in Fig. 11 (the arrowed structure). The rosette like zirconium rich structures shown in Fig. 11 should be similar in nature although most of them do not show a particle at the centre in this particular ficld of view. This is because only those particles that happen to have been sectioned through are visible in the subsequently polished microstructure. The major difference between the zirconium rich structures shown in Fig. 11 and those shown in Fig. 7a are therefore the morphologies of the zirconium rich structures due probably to the different zirconium and iron contents in the melt before casting

The presence of zirconium particles and a low zirconium matrix indicates that zirconium has not dissolved sufficiently to bring the licquid to the equilibrium content of $0-45 \%$ Zr (Fig. 10). Therefore, a melt that contains much less than $0.45 \% / 1 \mathrm{Zr}$, say $0.2 \%$, is stable to a temperature below the peritectic temperature. When the temperature decreases below the $\alpha$-Mg liquidus at approximately $652 \mathrm{C}, \gamma-\mathrm{Mg}$ begins to solidify according to the $\mathrm{Mg}$ Zr phase diagram (Fig. 10). Since the zirconium particles are excellent nucleants for $\alpha-\mathrm{Mg}$, the $\alpha-\mathrm{Mg}$ grains will nucleate on zirconium

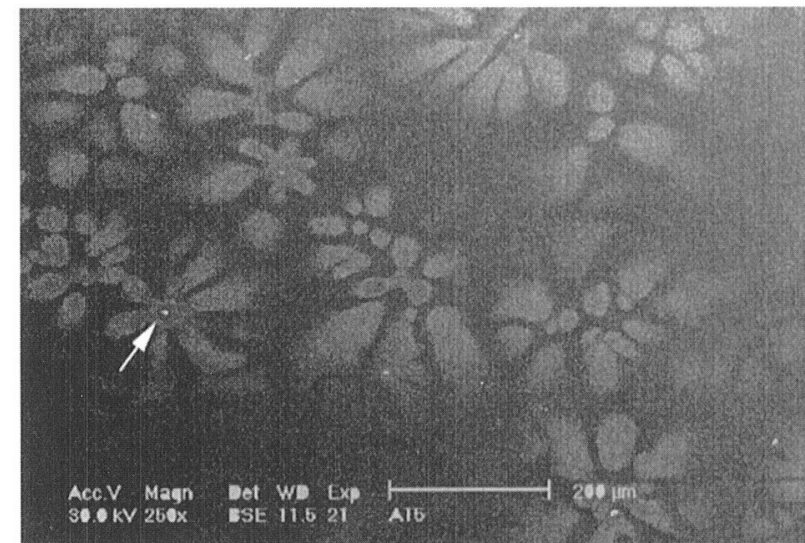

11 Rosette like zirconium rich structures observed in sample containing only $0 \cdot 19 \%$ soluble zirconium. Note that the structure arrowed in this micrograph contains a tiny zirconium particle at the centre, a circular core surrounding the particle, and developed dendrite branches surrounding the core

particles in the melt. A peritectic reaction is not necessary and plays no part in this process. In fact, even il the liguid composition reached equilibrium during solidification. a peritectic reaction is probably not likely to occur as observed in other peritectic systems such as $\triangle 1$ Ti alloys. "The solidification process of a low zirconium content magnesium alloy is therefore simply the crystallisation of $\%$-Mg glatins onto the zirconium particles, which are excellent nucleants for $x-\mathrm{Mg}$. It is proposed that the rosette morphology of the zirconium rich $\gamma$-Mg is related to the soluble rireonim and iron contents in the melt before casting (1ig. 11). Further work is required to fully understand the lormation ol rosette like rirconium rich structures in low rirconium content magnesium alloys

\section{Summary}

1. The uptake of iron by molten matgessium from uncoated mild steel crucibles was sluggish all $680($. The use of $0.05 \% / \mathrm{Zr}$ addition could cllectively suppress the increase in the iron content within the first 2 h of hold at $680 \mathrm{C}$. Little increase in the iron content wats observed throughout the 6 h of holding at 680 (C when $0.25 \% 1 / \mathrm{x}$ Wats alloyed to the melt.

2. Rapid and severe uplake of iron was observed al $780 \mathrm{C}$. The uptake of iron at 7.30 ( was conspicuous but was still controllable by use of $0.05 \%$. within the list hour of holding at $730 \mathrm{C}$. The use of $0.25 \% / 1 \%$ could significantly suppress the increase in the iron content at both temperatures.

3. The uptake of iron demonstrated a signifieant influenee on the grain refinement of pure magnesium by tireoniam at both $730 \mathrm{C}$ and $780 \mathrm{C}$. It was found that the grain relinement of pure magnesium achieved by $1 \% / 1 / 4$ addition nearly vanished after 1 h of holding at 780 ( due to the uplake of iron. The work conducted using an aluminimm titanite crucible and a boron nitride coated mild steel crucible al 730 C further confirmed the highly detrimental influence of the uptake of irom. In these experiments, the soluble zirconium remained constant and exeellent gratu relinement was readily restored by stirring and bringing the zireonium particles back to the melt.

4. The zireonium rich coring structures were observed to develop from circular to rosette like when the melt wats held in an uncoated stcel crucible at 730 C and 780 ('due to the consumption of soluble zirconium and the uptake of 
iron. No such morphological evolution was observed when aluminium litanite crucibles were used. It is proposed that the rosette morphology of zirconium rich $x$ - $\mathrm{Mg}$ is related to the soluble rirconium and iron contents in the melt before casting.

\section{Acknowledgements}

This work wats funded by the Australian CRC for Cast Metals Manulacturing (CAST). CAST was established under and is supported in part by the Australian Government's Cooperative Research Centres Scheme. One of the authors (P. (ao) would like to acknowledge a scholarship received under the University of Queensland International Posigraduate Research Scholarships (UQIPRS) programme. The authors would like to thank $\mathrm{Mr} \mathrm{X}$. Yuan and Ms I. Zheng of the University of Queensland. Australia for their help with the experimental work. Valuable comments and suggestions from the reviewer aro appreciated

\section{References}

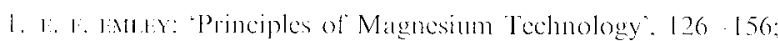
1966, Oxford. Pergamon

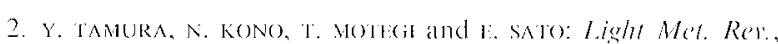
199). 6, (7), $20 \quad 25$

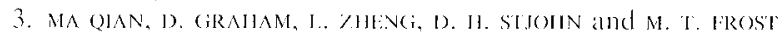

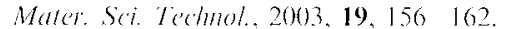

4. Е. I. 1:Mar: "Principles of magnesium technology", $183 \quad 100$; 1960, Oxford, Pergamon

5. WA OIAN, D, IJ. SIJOHIN and H. T. hROST: 'Magnesium alloys and their applications". Wollsburg, Germany, November 2003 $706712: 2003$, Weinheim. Wiley-VC'II.

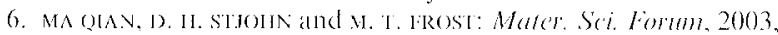
$419-422,593,598$.

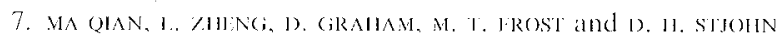
J. Lighlt Mol. 2001.1. $157 \quad 165$

8. MA (OAN. 1). H. STHIN and M. T. IROST: "Magnesium fechnology $2003^{\circ}$, (cd. II. I. Kalplan), 215 220; 2003, Warrendale. PA, TMS.

9. WA (o[A, 1), H. SIJOHN and w. I. lRost: "Magnesium technology 2003', (ed. H. I. Kaplan). 2099 214; 2003, Warrendale, $P \wedge$. TMS

10. MA (QAN, 1), H. SIJOHN and M. T. HROST: Ser. Mater, 2002, 46, (64) 654

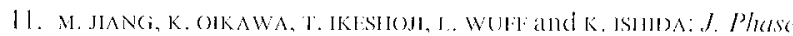
Equilihria, 2001, 22, 406 417.

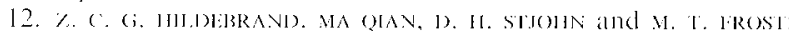
'Proc. Light metals technology conl'. 2003', (od. A. Dahle), 195 198; 2003, Brisbane. CAST Centre Pty.

13. E. 1: l:Mr J:Y: 'Principles of magnesium technology', 260 261; 1966, ()xford. Pergamon.

14. 11. (KAworo: "Phase diagrams of dilute binary alloys", 170; 2002. Materials Park, OH, АSM International.

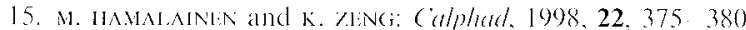

16. 1). II. SIJoHn: Acta Metall. 1990, 38,631 636 